\title{
Facilities Management of Samapta Sports Center in Magelang City
}

\author{
Khoiril Anam ${ }^{1}$, Nur Ahmad Taufikurrahman ${ }^{2}$ \\ \{khoiril.ikor@mail.unnes.ac.id ${ }^{1}$, taufikast12@gmail.com $\left.{ }^{2}\right\}$ \\ Universitas Negeri Semarang, Semarang, Indonesia ${ }^{1,2}$
}

\begin{abstract}
This research aimed to know the management and utilization of Samapta Sports Center in Magelang city. This research is qualitative. The results of this research showed that the management of the facility in Samapta Sports Center was divided into planning, organizing, actuating, and controlling. Based on the research could conclude that facility management of Samapta Sports Center that was done by the Department of Youth Sport and Tourism (Disporapar) of Magelang city was good. The organizing used the indicator of planning, organizing, actuating, and controlling. The utilization of the facility of Samapta Sports Center by the society was good. The citizen is aware of how important doing sport was. However, the application of it still low. The utilization that was done including the indicator of educational sports, recreational sports, and achievement sports.
\end{abstract}

Keywords: Management, sports facilities, Magelang.

\section{Introduction}

The law that was arranged about national sports system Chapter 1 Section 1 Number of 4 explained that sport is the systematic activities that motivate, build and improve body potential, spiritual and social (Law of Number of Year 2005). The goal of national sport in Law Number of 3 Year 2005 Section 4 stated that national sport has purpose to protect and increase healthy and vitality, achievements, human quality, build moral value, sportsmanship, discipline and tight the unity of the nation, support the national endurance and lift up the level, grade and the respectability of the nation [1]. Sport is physically activity that is done to get health and strong body. Sport is a physically activity that it is positive thing and can make the body and spiritual healthy and also motivate, build and increase the potential of physics. Sport cannot be separated from the tools as the facility provider to do sports. Moreover, it is needed a good management of sport facility.

The sport management facility is a process including planning, administrating, coordinating, and assessment of daily implementation from sport facility [2]. Sport facility needs expensive cost, is it outdoors or is it indoors. The construction needs much costs and also the treatment [3]. Sport facility is all about thing that is used for support the activities that cannot be brought everywhere, it is permanent for example hall, swimming pool, field: grass/synthetic football, hard: tennis, badminton, gravel: softball, volley, track and field jogging track, sand: beach volley. Sport facility has several types such as 1) single facility, it is a facility that is general used for one branch of sport, 2) multi use facility, $t$ is a facility categorized indoors or outdoors, 3) facility in club house, it is a facility that completed by 
outdoors or indoors facility that is completed by items storage box, toilet, shower restaurant, and sport store, 4) facility of big sport, it is a facility that not only provides rooms for practice sport but also for the spectator [4].

Sport facilitate is a source of sport including physical facilitate and non-physical facilitate. Physical facilitate include the facilitation and physical facilitation such as stadium, arena and field. Furthermore, nonphysical sport such as target / association of sport, coach and teacher of sport. The available of that kind of facility of sports in enough number will increase the participation of society to do the sports. Be sides, in the right time will change the mind of society about sport that it is not only for recreation, keep the body health but also to reach the achievements [5][6][7].

One of facility that belongs to the government in sport aspect is arena of sport. Arena sport is a building that is used for sport activities in close room or indoors. Arena sport as the facility of sport should have good tools and infrastructure. Tools is one of the important elements that should be completed in sport. it is state that tools are all of things that is used for reach the goals. However, the infrastructure is all the things that is the main support for the process of effort, project building and many others. Tools and infrastructures are all the equipment that can support sport activity such as field sport building with the equipment that including base principal of infrastructure in, completeness of infrastructure, the quality and quantity of tools and infrastructures.

Samapta Sport Center is one of government's sport facility that is located in Magelang city. This sport center is built to reach the goal of Magelang city to make Magelang city as an epicentrum of service that is supported by good quality human source and good facility with Magelang city's region regulation Number 4 Year 2009 about planning in long of period time. Magelang city's region Year 2005-2025. Appropriate with letter of judgment of Mayor of Magelang Number 020/96/112 Year 2018 about the decision of the employing status of Samapta Sport Center in Department of Youth Sport and Tourism (Disporapar) year 2018, the management organization of Samapta Sport Center is legitimate belongs to Department of Youth Sport and Tourism (Disporapar) Magelang city.

Samapta sport center is located in Sanden, South Kramat sport center, North Magelang, Magelang city. Samapta Sport Center was renovated several times, the last renovation was finished in December 2017. Samapta Sport Center is designed with warped roof, field indoor with cement floor, full of color seat for the spectator, front fence and security post. Based on the research that has title "Sports Coaching Achievements in Magelang City" related to the sport regulation still can find several problems such as the ineffectiveness of regulation region Number 4 Year 2015 about the implementation of sport central java province in facilitate the regulation of reconstruction of achievement sport, the low of awareness about future athletes and others [8].

The awareness about how important doing sport increases. Sport is important for body since doing sport make the body keep health and avoid to disease, sport is expected to be medicine [9][10][11][12]. The scope of sport such as 1) educational sport, 2) recreational sport, 3) achievement sport [13][14][15]. The purpose of person doing sport such as sport for education, sport for recreation and sport for achievement. However, nowadays society implement about the purpose of doing sport in Samapta Sport center.

Based on the researcher's research, the researcher found that renovation gives new face to Samapta Sport Center. In interview with Ali Mahrus Alkafi, a head of empowerment and development achievement sport in Department of Youth Sport and Tourism (Disporapar), Magelang city that also as the organizer Samapta Sport Center stated that facility in Samapta Spot Center is satisfy enough and the visitor is busy enough. However, he found the lack of it 
such as the seat of spectator is not high yet, damage roof, the organize of water, the limited facilitation for pray and there is no canteen there. The sanitation is not well organized yet such as glossy floor, too many dusts it because there is only little office boy.

Samapta Sport Center provides place and facility for many branches sport such as volley ball. Basketball, badminton and self-protect sport. For indoors football (futsal) sport, Samapta Sport Center not provides the tools and infrastructure/ it because the goal of Department of Youth Sport and Tourism (Disporapar) of Magelang city wants to make private indoors football (futsal) in Magelang city busy.

Many communities use Samapta Sport Center, with facilities that were provided by Samapta Sport Center support all sorts of sports that were done by society of Magelang. Be sides for society's activities, Samapta Sport Center is also for event place the government or private. It could be seen from many of utilizing Samapta Sport Center's facility, the researcher was interested to do research and takes undergraduate thesis about "The Facility Management of Samapta Sport Center in Magelang City"

\section{Method}

The method that was used in this research was descriptive qualitative method. Qualitative method in a research means to understand the phenomenon about what the subject concerned such as behavior, perception, motivation, holistic action by descriptive in words and language in natural context by using natural method [16]. Qualitative method is a method research that can express the truth based on the results from the collecting data in factual manner that is done by the researcher. Qualitative method is an assessment procedure that has result a descriptive data from written source or expressing and behavior [17]. Descriptive method is a method to do research for a group of humans, object, condition, thinking system or nowadays phenomenon.

The collecting data technique using several techniques such as observation, questionnaire, interview and documentation. the subject of this research was the organizer of facility the head section for sports empowerment and development of the city of Magelang's Department of Youth Sport and Tourism (Disporapar), The head of unit executor technique of Samapta Sport Center and the society of Magelang that uses Samapta Sport Center's facility. 
Table 1. Questionnaire grid (questionnaire)

\begin{tabular}{|c|c|c|c|c|c|c|}
\hline Number & Target & & Indicator & Sub indicators & Number & Amount \\
\hline \multirow[t]{11}{*}{1.} & People & using & General & a. Sports goals & 1,2 & 2 \\
\hline & Samapta & Sports & & b. History of & 3,4 & 2 \\
\hline & Center & & & sports facilities & 5,6 & 2 \\
\hline & & & & $\begin{array}{l}\text { c. Complete } \\
\text { sports facilities } \\
\text { d. Opinions } \\
\text { regarding sports } \\
\text { facilities }\end{array}$ & 7,8 & 2 \\
\hline & & & Utilization & a. Benefits of & 1,2 & 2 \\
\hline & & & for Education & $\begin{array}{l}\text { sports facilities } \\
\text { b. Opinions } \\
\text { regarding sports } \\
\text { facilities }\end{array}$ & 3 & 1 \\
\hline & & & Utilization & a. Benefits of & 1,2 & 2 \\
\hline & & & $\begin{array}{l}\text { for } \\
\text { Recreation }\end{array}$ & $\begin{array}{l}\text { sports facilities } \\
\text { b. Opinions } \\
\text { regarding sports } \\
\text { facilities }\end{array}$ & 3 & 1 \\
\hline & & & Utilization & a. Benefits of & 1,2 & 2 \\
\hline & & & & sports facilities & 3 & 1 \\
\hline & & & $\begin{array}{l}\text { Achievement } \\
\mathrm{s}\end{array}$ & $\begin{array}{l}\text { b. Opinions } \\
\text { regarding sports } \\
\text { facilities }\end{array}$ & & \\
\hline
\end{tabular}

Table 2. Interview grid

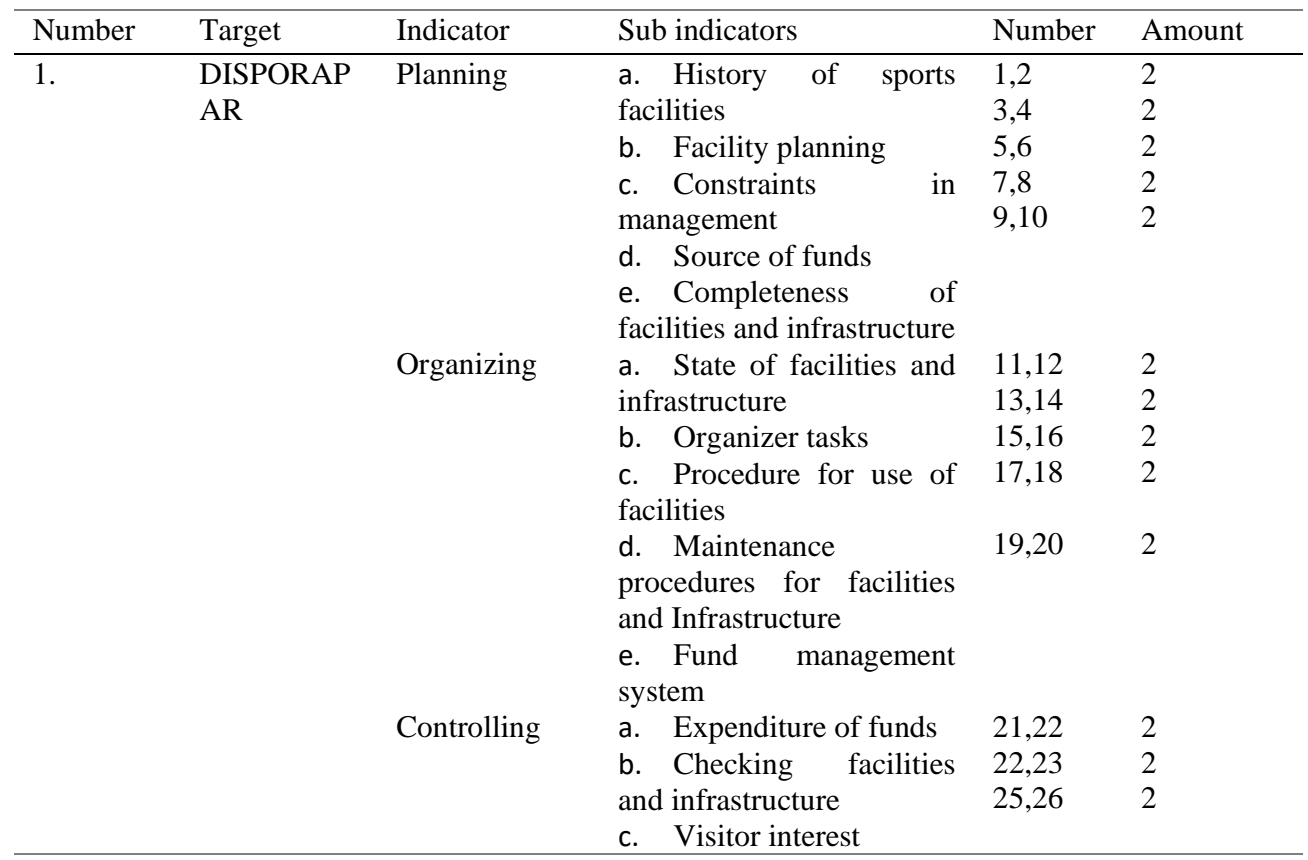




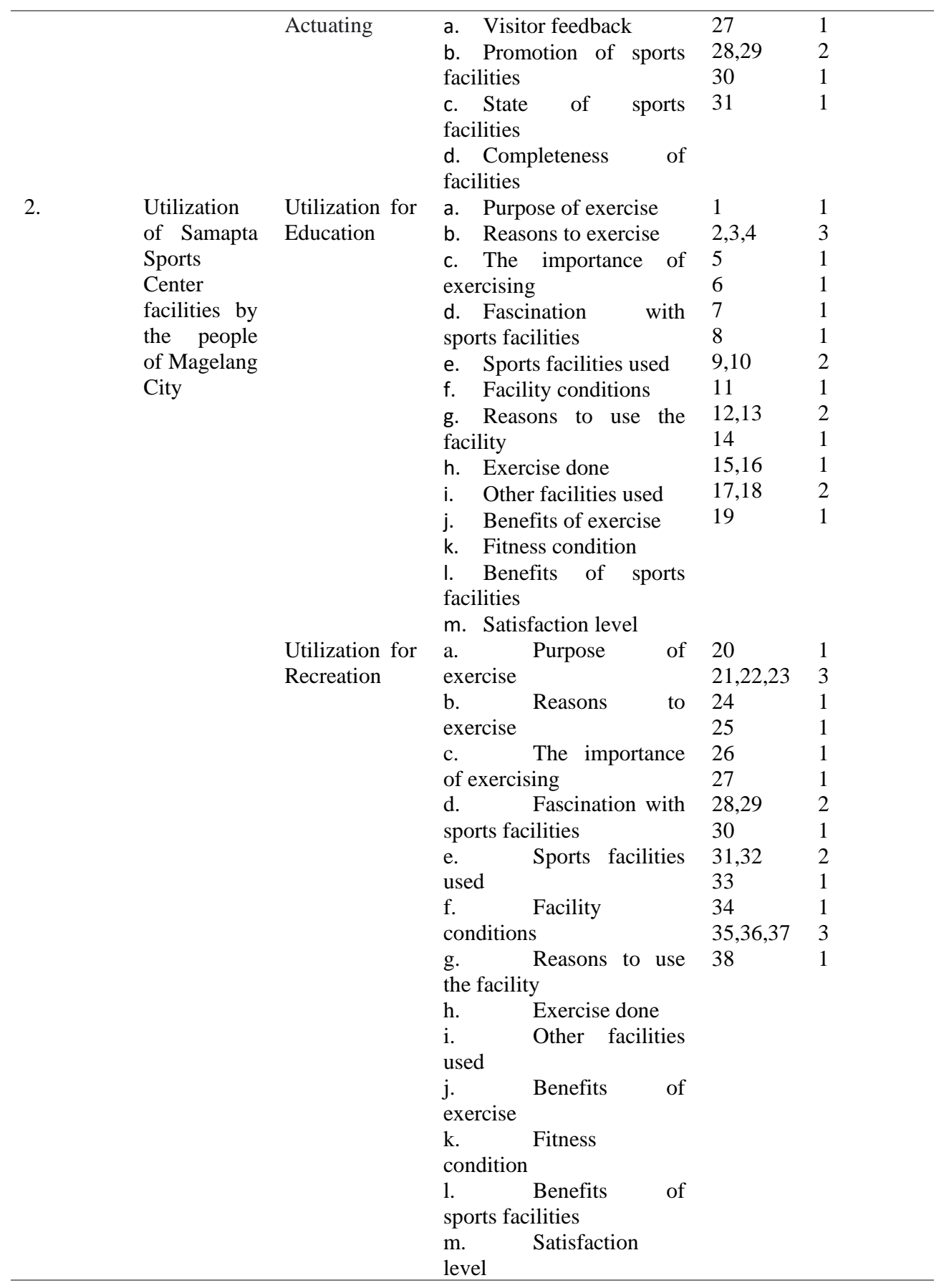




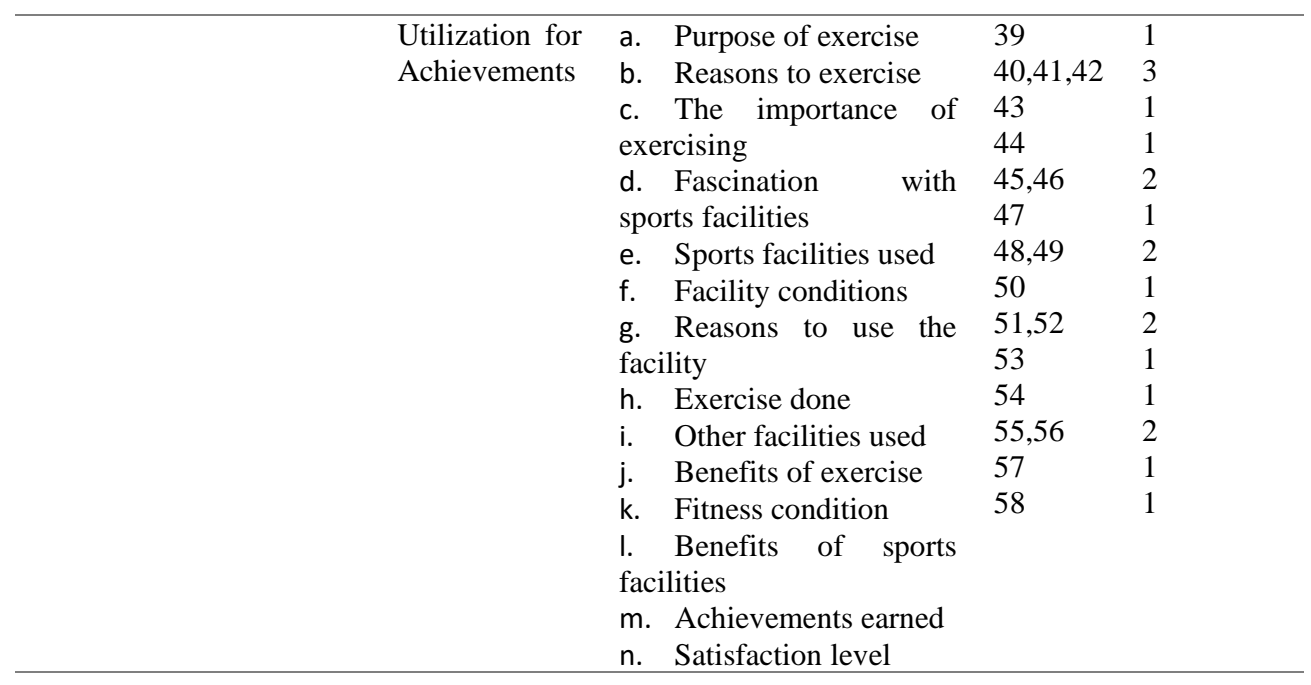

A source or informant is the one who provides information. The source in this case is the one who can provide oral information about something that wants to know. The speakers in this study are actors who use facilities and managers of Samapta Sports Center in Magelang City.

The technique of checking the validity of the data used in this study is triangulation. Triangulation is a technique of checking the validity of data that utilizes something other than that data to check or as a comparison to that data [4]. Triangulation means the best way to eliminate differences that exist in the context of a study during the collection of data on events and relationships from different views. Researchers can check their findings by comparing them from a variety of sources, methods, or theories. Therefore, researchers can do it by 1) Submit various variants per question, 2) Check with various data sources, 3) Make use of various methods so that checking the data trust can be done. Data triangulation used here is a triangulation of data sources i.e., researchers dig information from three data sources.

\section{Results and discussion}

Facility management of Samapta Sport Center was divided into several indicators such as planning, organizing, actuating, and controlling. Appropriate with letter of judgment of Mayor of Magelang Number 020/96/112 Year 2018 about the decision of the employing status of Samapta Sport Center in Department of Youth Sport and Tourism (Disporapar) year 2018, the management organization of Samapta Sport Center was legitimate belongs to Department of Youth Sport and Tourism (Disporapar) Magelang city. Based on the observation results with the official of Department of Youth Sport and Tourism (Disporapar) of Magelang city as the organizer of Samapta Sport Center with using those indicators. In the implementation Department of Youth Sport and Tourism (Disporapar) of Magelang city was helped by action technique unit of sport center, The UPT has done the master plan program for planning process in organizes Samapta Sport Center. 


\subsection{Planning}

The management of Samapta Sports Center facilities begins with planning indicators. To run the management of Samapta Sports Center, the manager does planning through the program. UPT (Task Force) conducted a master plan program in the sports center area in the planning process at Samapta Sports Center. In the master plan set about the planning of development in the sports center area which there has been documented in RT/ RW that there will be no development in the sports center area but only for the construction of buildings and sports infrastructure.

This master plan is prepared for the next 10 years with the aim that when there is a change of leadership will not affect the development in the sports center area itself. UPT also said that with the master plan program, Samapta Sports Center can develop into a good sports area in a vulnerable time that has been planned.

The planning of the UPT itself is more focused in terms of building infrastructure development which is not only Samapta Sports Center but there will be the construction of other sports halls in the area. For Samapta Sports Center itself, UPT continues to develop in it, from pre-retirement facilities, supporting facilities, and other needs such as bathrooms and mosques.

UPT also plans to develop facilities in Samapta Sports Center by installing fitness equipment at several points. The tool is intended to support sports activities in the Samapta Sports Center. The device is planned to be installed in March 2020.

New regulations from UPT regarding the use of Samapta Sports Center especially in the inner area for musical performances or concerts using the stage also began to be applied. UPT prohibits all forms of stage establishment in the area within Samapta Sports Center, this aims to keep the floor from being easily damaged.

\subsection{Organizing}

The second indicator of Samapta Sports Center facility management is organizing. UPT has its members manage Samapta Sports Center facilities. In the membership of UPT itself includes the division of tasks such as maintenance, security, leasing, promotion, and fund management.

The first task is maintenance, from the results of interviews conducted by officers from UPT, maintenance here includes all infrastructure facilities in Samapta Sports Center. In addition to the maintenance of officers here are also assigned to maintain cleanliness in the Samapta Sports Center. To perform maintenance, UPT has 6 personnel to perform maintenance and maintain cleanliness in the Samapta Sports Center area. The second task is security, in organizing the UPT assigns security guards in turn to maintain security. The job of the security guard itself is to maintain security in the sports center area, not just the Samapta Sports Center area. For security, it has 9 personnel are assigned in turn 24 hours. The third task is rental, in this indicator the head of UPT directly manages it in the sense that the party who wants to rent Samapta Sports Center directly meets with the head of UPT. Those who want to use Samapta Sports Center meet the Head of UPT is the office located in the sports center area, then in the process to make payments.

The next task is promotion, in conducting the promotion of UPT parties to approach through the community and clubs in Magelang City. UPT was assisted by The Disporapar of Magelang City through the official website to promote Samapta Sports Center. In the promotion, UPT also conducts CFD (car-free day) activities in the sports center area. CFD 
activities are conducted every Sunday from 06.00 - 10.00 a.m., this activity is conducted to introduce and increase public interest in doing sports at Samapta Sports Center. The last task is the management of funds, in the management of funds carried out directly by the head of UPT regarding the income and expenditure of all documented, which will be made a report and given to the Disporapar Magelang city. UPT itself admits that organizing here still needs to be improved. In addition to the few personnel, coordination between personnel also needs to be considered again to achieve the common goal.

\subsection{Actuating}

The third indicator of Samapta Sports Center facility management is the driver. The head of UPT who is in charge at Samapta Sports Center stressed that his subordinates should report what they are doing. The head of UPT is required to be able to move his subordinates to work well and effectively. In addition to his ability to manage the management of Samapta Sports Center, the head of UPT must also utilize existing personnel to fulfill the positions that are still vacant. The head of UPT relation as the mobilizer has a regular meeting agenda of all members of the sports center area, which is conducted discussion and evaluation of the performance that has been done. This aims to be able to improve what is still lacking and has not been done to be able to further develop the sports center area.

In its performance, UPT continues to coordinate with the Disporapar of Magelang City. Every performance performed must have a report that will be submitted to the Disporapar Magelang city for checking and evaluation for the future.

\subsection{Controlling}

The fourth indicator of Samapta Sports Center facility management is supervision. The Head of UPT supervises all performance performed by its members to ensure the work carried out is by the predetermined planning. In his supervision, the first Head of UPT set the standard of implementation, whether each member has done his/her duties according to standards or not. Then make corrections if the implementation of the duties of the members is not by the standards that have been set. Supervision is the final stage of the management process of Samapta Sports Center, where supervision is carried out so that previous indicators, namely planning, organizing, and mobilizers can be carried out properly.

In its performance, the UPT is still under the supervision of the Magelang City Disporapar. The highest supervision here is held by the Disporapar of Magelang City related to the management carried out by UPT. Supervision of the Magelang City Disporapar itself determines how the process carried out by UPT can run well.

\section{Conclusion}

1. Facility management of Samapta Sport Center that had done by Department of Youth Sport and Tourism (Disporapar) of Magelang city was well. In organizing they used several indicators such as planning, organizing, actuating and controlling.

2. The utilization of Samapta Sport Center by the society is well. The society of Magelang are aware how important doing sport was. However, in the implementation still low 
enough. The utilization that has done including several indicators such as educational sport, recreational sport and achievement sport.

3. Subsequent research is expected to be able to examine the role of Samapta Sports Center for the surrounding residents.

Acknowledgement. The researcher awarded that this article could not be separated from the assistance of many sides, in this occasion the researcher delivered thanks expression to Department of Youth Sport and Tourism (Disporapar) of Magelang city.

\section{References}

[1] Pambudi DK. Analisis Standarisasi Fasilitas Gedung Olahraga Universitas Negeri Yogyakarta. MEDIKORA. 2020;19:46-52. https://doi.org/10.21831/medikora.v19i1.30887.

[2] Rahmawati ID. Manajemen Sumber Daya Olahraga Tenis Lapangan. J Pinus 2017;3:25-31.

[3] Winda Fatmasari 6102415023. SURVEI MANAJEMEN OLAHRAGA GULATKLUB WRESTERLING DI KABUPATEN BLORATAHUN 20182019.

[4] Harsuki. Pengantar Manajemen Olahraga. Jakarta: Rajawali Pers; 2013.

[5] Akhmad N, Zainudin F. Analisis Potensi Manajemen Perencanaan Prestasi Dan Sistem Informasi Koni Kota Mataram. JUPE J Pendidik Mandala 2019;4. https://doi.org/10.36312/jupe.v4i4.923.

[6] Pratama R, Komaini A. TINJAUAN MANAJEMEN PENGELOLAAN OBYEK WISATA OLAHRAGA REKREASI KAMPOENG RADJA. J STAMINA 2019;2:203-11. https://doi.org/10.24036/JST.V2I5.368.

[7] Adrianto A, Syamsurizaldi S, Zetra A. Manajemen Program Pengembangan Destinasi Pariwisata oleh Dinas Pariwisata, Kebudayaan, Pemuda dan Olahraga Kabupaten Kerinci. J Adm Dan Kebijak Publik. 2019;3:226-38. https://doi.org/10.25077/jakp.3.3.226-238.2018.

[8] Febihantoro A. Pembinaan Olahraga Prestasi di Kota Magelang (Analisis Tentang Kebijakan, Pendanaan, dan Sarana dan Prasarana Olahraga. Universitas Negeri Semarang, 2018.

[9] Oja P, Titze S, Kokko S, Kujala UM, Heinonen A, Kelly P, et al. Health benefits of different sport disciplines for adults: Systematic review of observational and intervention studies with metaanalysis. Br J Sports Med. 2015;49:434-40. https://doi.org/10.1136/bjsports-2014-093885.

[10] Khan KM, Thompson AM, Blair SN, Sallis JF, Powell KE, Bull FC, et al. Sport and exercise as contributors to the health of nations. Lancet. 2012;380:59-64. https://doi.org/10.1016/S01406736(12)60865-4.

[11] Parnell D, Spracklen K, Millward P. Sport management issues in an era of austerity. Eur Sport Manag Q. 2017;17:67-74. https://doi.org/10.1080/16184742.2016.1257552.

[12] da Silva LA, Tortelli L, Motta J, Menguer L, Mariano S, Tasca G, et al. Effects of aquatic exercise on mental health, functional autonomy and oxidative stress in depressed elderly individuals: A randomized clinical trial. Clinics. 2019;74. https://doi.org/10.6061/clinics/2019/e322.

[13] Sudagung YB. Kawasan Olahraga Rekreasi Pada Ruang Terbuka Hijau Di Kota Pontianak. JMARS J Mosaik Arsit. 2015;3. https://doi.org/10.26418/JMARS.V3I1.10179.

[14] Utami D. Peran Fisiologi Dalam Meningkatkan Prestasi Olahraga Indonesia Menuju SEA GAMES. J Olahraga Prestasi. 2015;11:52-63. https://doi.org/10.21831/jorpres.v11i2.5728.

[15] Nugraha B. Pendidikan Jasmani Olahraga Usia Dini. J Pendidik Anak. 2015;4:557-64. https://doi.org/10.21831/jpa.v4i1.12344.

[16] Lexy J. Moleong. Metode Penelitian Kualitalif. Bandung: PT. Remaja Rosdakarya; 2012.

[17] Ashofa B. Metode Penelitian Hukum. Jakarta: PT. Rineka Cipta; 2013. 